\title{
The Development of Islamic Education and Strengthening of National Education System of Indonesia
}

\author{
Suryawahyuni Latief ${ }^{1}$, Yeasy Agustina Sari ${ }^{2}$, Muhammad Yusuf ${ }^{3}$, Armila ${ }^{4}$, Riyan \\ Erwin Hidayat ${ }^{5}$ \\ 1 Universitas Nurdin Hamzah Jambi, Indonesia \\ 2,4,5 Institut Agama Islam Negeri (IAIN) Metro Lampung, Indonesia \\ 3 Sekolah Tinggi Agama Islam Al-Furqan Makassar, Indonesia
}

yeasy120708@gmail.com

\begin{abstract}
This article aims to analyze the development of Islamic education in Indonesia and efforts to strengthen it in the national education system. This type of research is descriptive qualitative. The study of literature by focusing on terms of peeling, summarizing and collecting a literature, then the authors provide an analysis of the data that has been collected. The results showed that during the pre-independence era religious education was not only not recognized but also not included in the education system, it was even suspected of being a place to incite and fight the invaders. At the time of independence it did not yet have a role because the government still tended to be controlled by nationalist and secular groups, if there were Islamic groups, Islam was still more abangan. Thus the New Order government continuously fostered the quality of madrasa education so that in 1975 a joint decree (SKB) was issued by three ministers on Improving the Quality of Education in Madrasas, where the SKB of the three ministers had advantages and disadvantages. So that the solution of this weakness is the government is trying to make breakthroughs to restore the function of the madrasa as a place to print religious leaders, namely by opening an alternative Madrasah Aliyah named Madrasah Aliyah Special Program (MAPK). Henceforth, this MAPK was changed to Madrasah Aliyah Religious (MAK) which focuses and strengthens the field of Islamic education. There are two strengthening of Islamic education in the national education system, namely strengthening Islamic educational institutions, and strengthening religious subjects in all schools both under the auspices of the Ministry of Religion and other Ministries.
\end{abstract}

ARTICLE INFO

Article history:

Received

June 02, 2021

Revised

July 02, 2021

Accepted

July 04, 2021

Keywords: National Education System of Indonesia, Development of Islamic Education, Strengthening National Education System

How to cite

Latief, S., et al., (2021). The Development of Islamic Education and Strengthening of National Education System of Indonesia. IJoASER (International Journal on Advanced Science, Education, and Religion), 4(2). 86-99. https://doi.org/10.33648/ijoaser.v4i2.105

Journal Homepage https://ojs.staialfurqan.ac.id/IJoASER/

This is an open access article under the CC BY SA license

https://creativecommons.org/licenses/by-sa/4.0/ 


\section{INTRODUCTION}

The agenda of universal problems faced by humans today, the most interesting to discuss is education. Education has been and will always be most responsible for the development of human civilization. When looking at a narrower scope, on a national scale, approximately 27 million Indonesians are still living in poverty (Lee \& Ryu, 2019; Syafutra, et al., 2021; Hadna \& Kartika, 2017). This problem shows that Indonesia is the largest concentration center of Muslims in the world. Thus, the problems faced by the Indonesian people are the problems of Muslims as well. So that it can be understood that the problem of education in Indonesia is actually a problem faced by Islamic education.

In the context of Islamic education in Indonesia, until now it is still clearly seen that the existence of madrasas has not occupied a strategic position in the national education system. The transfer of its management to the Ministry of Religion (now the Ministry of Religion) seems to be solely based on this consideration (Fajrussalam, et al., 2021; Setiyanto, et al., 2021). Efforts to reformulate and develop a curriculum so far do not seem to be a reason to recognize this institution as an important part of the national education system (Mahfud, 2019; Setiawan., 2020). However, adhering to the existing laws and regulations, integrating madrasas into the national education system also does not fully benefit Muslims (Maksum, 1999). By becoming part of the national education system, madrasas will indeed get the same status as schools, but with this status there is a consequence that madrasas must be managed by the Ministry of Education and Culture (now Kemendikbud) which is the only government agency responsible for providing education. general and vocational. The latter is not approved by Muslims who prefer the management of the madrasa under the Ministry of Religion.

The existence of the Indonesian Islamic education system is faced with various prblems, including: the recognition of graduates produced by madrasas as an Islamic education system to the problem of madrasa governance which seems chaotic. Meanwhile, developments in social life forced the madrasa to exist without sacrificing the values that had been pioneered by the scholars as the founders of the madrasa (Asnawan, 2021; Romlah \& Latief, 2021; Wahyuni, et al., 2021). In such an atmosphere, of course, madrasas must change the paradigm as "wild" educational institutions as the label was once given by the Dutch colonial government to become educational institutions that follow the policies of the Indonesian government in improving the quality of education nationally. After all, the Indonesian Islamic education system has become part of the National Education System and the Unitary State of the Republic of Indonesia (Fitriani, 2011).

While Ismail in his research concluded that there were several implications due to the political education policies carried out by the ruling government at that time on Islamic education. Starting from pre-independence, post-independence (including the old order, the new order, and the reform order as it is today), all of these political education policies have serious implications for the development of Islamic education in Indonesia. for example, the implications of madrasah education political policies on aspects of madrasa management in Indonesia are: (1) madrasas are reluctant to respond to policies on education autonomy and central-regional financial balance. (2) The occurrence of an imbalance in madrasa education policies causes gaps in the management of general education institutions and madrasas. (3) Madrasah management is the sole responsibility of the Ministry of Religion. (4) Local governments are less concerned about madrasas because in Law No. 32/2004 on 
Regional Government article 7 (1) it is implied that madrasas are part of "religious" affairs which are one of the mandatory affairs of the central government whose authority is not delegated to regional government. (5) The Ministry of Religion cannot be optimal in efforts to improve the quality of madrasas (Ismail, 2010). Based on the explanation above, basically this research aims to conduct a critical analysis of the regulation of Islamic education which is reflected in the National Education System. As explained above, there are still many national education policies contained in the National education system law that have not been in favor of Islamic education. This of course must be studied together so that constructive solutions will be found in the context of developing Islamic education in Indonesia.

\section{METHOD}

This study uses a qualitative approach with descriptive analysis. The data collection technique was carried out by literature review/literature study related to Islamic education in Indonesia. In other words, the term Literature Study is also very familiar with the term literature study. There are several methods that can be done to make Literature, like peeling(criticize),comparing(compare),sums up(summarize), and put together(synthesize)a piece of literature. Thus, the method used in this paper is a literature study with an emphasis on peeling, summarizing and collecting a literature, then an analysis is given of the data that has been collected

\section{RESULT AND DISCUSSION}

\section{The Development of Islamic Education in Indonesia}

After Indonesia's independence, Muslims increasingly realized the importance of the struggle of Muslims in achieving independence, and the government tried to improve Islamic education in Indonesia. 2 of 1989 concerning the National education system which was continued by Law no. 20 of 2003 which regulates the implementation of a national education system, as an effort to integrate Islamic education into the national education system, this paper will discuss Islamic religious education in the national education system.

Islamic education (religious lessons) has been taught in public schools since Indonesia's independence in 1945. During the first Indonesian cabinet in 1945, the first Minister of Education, Teaching and Culture, Ki Hajar Dewantara, had sent circulars to regions stating that Moral lessons that existed during the Japanese colonial period were still allowed and renamed to Religion lessons. At that time, religious education was not required to be given to public schools, but was voluntary/facultative, and did not determine the increase/graduation of students. Islamic education has the status of a basic subject in public schools from elementary to tertiary institutions based on TAP MPRS number XXVII/MPRS/1966 Chapter I Article I which reads: "Determining religious education to be a subject in schools starting from elementary school up to State Universities". This regulation came out without protest, after the crushing of the PKI.

The implementation of Islamic education in general and Islamic religious education in particular in public schools has been strengthened by various subsequent issuances of legislation, until the issuance of Law Number 20 of 2003 concerning the National Education System which guarantees the fulfillment of religious education to students. And followed by the issuance of further regulations until the issuance of the Regulation of the Minister of Religion of the Republic of Indonesia Number 16 of 2010 concerning Management of Religious Education in Schools. 
With the increasingly strong position of Islamic Education in the Indonesian education system after experiencing a very long period of struggle, of course ideally it has shown significant results and the goals of Islamic religious education have been achieved, namely physical education, intellectual education and moral education (Salim, 2012). However, in reality on the ground, there are many problems that arise that result in not optimal Islamic religious education in schools, both at the elementary, junior high, high school and vocational levels.

If we return to the history of the development of Islamic education in Indonesia, especially in the context of integrating education into the national education system, the Joint Decree (SKB) of the three ministers is a regulation that can pioneer the strengthening of the position of Islamic education nationally. The Joint Decree of the three ministers was signed by three ministers, namely the Minister of Religion, the Minister of Education and Culture, and the Minister of Home Affairs. Number: 6 of 1975, Number: 037/U/1975, and Number: 36 of 1975 concerning Improving the Quality of Education in Madrasahs. The three ministerial decrees were signed in Jakarta by 3 ministers, namely: Dr. HA Mukti Ali (Minister of Religion), Dr. Syarief Thajeb (Minister of Education and Culture), and H. Amir Machmud (Minister of Home Affairs) on March 24, 1975 (Soebahar, 2013).

The Joint Decree (SKB) applies to madrasas and all levels, both public and private, both within the Islamic boarding school environment and outside the boarding school. The SKB aims to improve the quality of madrasa education so that it is equal to that of public schools. These parallels include: (1). Madrasah certificates can have the same value as public school diplomas; (2). Madrasa graduates can continue on to higher level public schools. (3). Madrasah students can transfer to public schools of the same level. This is emphasized again by detailing the sections that show the equality of madrasas with schools. In Chapter I, article 1, paragraph 2, for example, it is stated: Madrasah includes three levels: (1) Ibtidaiyah Madrasah, on the same level as Elementary School; (2) Madrasah Tsanawiyah, equivalent to Junior High School; (3) Madrasah Aliyah, equivalent to high school (Soebahar, 2013). Furthermore, in Chapter II article 2 paragraphs a, b, and c it is stated that: Paragraph a: Madrasah certificates can have the same value as public school diplomas of the same level. Paragraph $b$ : Madrasah graduates can continue to higher level public schools. Paragraph c: Madrasah students can transfer to public schools of the same level (Soebahar, 2013). Regarding the management and development, it is stated in Chapter IV article 4 as follows: (1) Madrasah management is carried out by the Minister of Religion. (2) The development of religious subjects in madrasas is carried out by the Minister of Religion. (3) Guidance and quality control of general subjects at madrasas is carried out by the Minister of Education and Culture, together with the Minister of Religion and the Minister of Home Affairs (Soebahar, 2013).

This Three Ministerial Decree can be seen as a more tangible acknowledgment of the existence of madrasas and at the same time a strategic step towards the stage of integration of madrasas into the complete National Education System. With this decree, madrasahs get a clearer definition as educational institutions that are equivalent to schools even though their management remains with the Ministry of Religion (Soprayani: 2010, 130). In this case, madrasas are no longer only seen as religious educational institutions or institutions that carry out learning obligations, but are already educational institutions that make Islamic religious subjects a basic subject of at least 30\%, in addition to general subjects. However, the Minister of Religion at the 
time, Mukti Ali, explained that in practice the two subjects could complement each other, so they were both $100 \%$ equal.

With the Decree of the Three Ministers, the Ministry of Religion carried out efforts to strengthen the madrasa structure in a more comprehensive manner. A number of decisions were made to regulate the organization and functioning of madrasas at all levels. The Ministry of Religion also issued a regulation regarding the equality of private madrasah certificates with public madrasah. In terms of the curriculum, it is carried out by rearranging the composition of general subjects. In line with the Three Ministerial Decree, the madrasa curriculum contains the same number of general subjects as the school curriculum at each level. Madrasas can thus be said to be schools plus religion (Maksum, 1999).

Recognition of the status of madrasah, followed by adjustments to the school system has produced a favorable response. Among them, the Presidential Instruction was obtained for a thousand madrasah in 1978 and a few years later came a request from the Chancellor of IPB, Prof. Dr. Andi Hakim Nasution to send some of the best graduates of Madrasah Aliyah as PMDK students at IPB. Madrasah Aliah Special Program (MAPK) is an anticipation of the declining ability in the field of religion in Madrasah Aliyah graduates after they turn into madrasas with a curriculum burden of $70 \%$ general and 30\% religious (SKB 3 ministers 1975). Especially after the National Education System Law no. 2 of 1989 which equates the school curriculum with madrasah, which distinguishes only the number of hours of religious lessons that are characteristic. At the elementary, junior high, high school level, religious lessons are 2 hours, then at MI it is 4 to 7 hours and at MTs and MA it is 9 hours (Rahim, 2005, p. 176). On the other hand, the public's concern about the decreasing number of religious experts (kyai/ulama) is the main reason for the opening of MAPK. Through this decree, madrasah status is equated with schools and their levels: MI is equal to SD, MTs is equal to SMP, and MA is equal to SMA. With this 3 Ministerial Decree, MA alumni can continue to public universities, and vice versa, high school alumni can continue their studies to IAIN/UIN. Because madrasas are recognized as being equal to general schools, the madrasa curriculum must be the same as schools, containing subjects with a ratio of 70\% general subjects and 30\% religious subjects (Rahim, 2005, p. 177).

The effect of this curriculum equation is an increase in the burden that must be borne by madrasas (Rahim, 177). On the one hand, he must improve the quality of education in general to the standards applicable in schools (Zuhdi, 2021). On the other hand, after all, madrasas as Islamic educational institutions must maintain the quality of their religious education. However, with only 30\% mastery of religious sciences including Arabic, it is not sufficient for MA alumni to enter IAIN/UIN, let alone become religious candidates. This fact makes Prof. Dr. Muhawir Sadzali, while serving as Minister of Religion (1983-1993), looked for a solution to what he called the "ulama crisis", namely by opening an alternative Madrasah Aliyah named Madrasah Aliyah Special Program (MAPK) with a curriculum composition of $70 \%$ religion and $30 \%$ general lessons plus intensive language teaching (Arabic and English) (Fathoni: 2005,98). With this program, IAIN's inputs can be qualitatively improved, and more importantly, become a supporter for the emergence of prospective ulama (Rahim, 2005, p. 178). On its journey, MAPK was later changed to MAK (Madrasah Aliyah Keagamaan) based on the Decree of the Minister of Religion No. 73 of 1987. This madrasa focuses on the development and deepening of the religious sciences without neglecting general knowledge as an effort to develop insight. To that end, a feasibility 
study was conducted to determine which madrasah were considered the most likely to be appointed as implementers of this program. Finally, 5 State Aliyah Madrasah were appointed as organizers, namely MAN Darussalam Ciamis West Java, MAN Ujung Pandang (now Makassar), MAN 1 Yogyakarta, MAN Kota Baru Padang Panjang, West Sumatra, and MAN Jember, East Java. Until 1993 this program had 16 MAN and 105 MAS (Hasbullah, 2016).bThe main objectives of opening this MAPK are: to meet the needs of experts in the field of Islam in accordance with the demands of national development in order to improve the quality of education at Madrasah Aliyah. To prepare graduates to have the basic skills needed for self-development as intellectual scholars. Preparing graduates as prospective students of IAIN/UIN or other PTAI including prospective students of Al-Azhar University Egypt (Rahim, 2005).

The implementation of MAPK involves the central and regional agencies in an integrated manner in their own team. Prospective students who will be accepted at MAPK are not random students, but must meet the specified requirements and go through a strict selection. According to the records of the Directorate of Madrasah Education, for the year 2017 as many as 432 (four hundred and thirty-two) people will be accepted as students of MAN PK. The 432 MAN PK students are spread across 10 (ten) provinces throughout Indonesia, namely: 1) MAN 1 Jember-East Java (48 students); 2) MAN Koto Baru Padang Panjang-West Sumatra (48 students); 3) MAN 3 Makassar-South Sulawesi (48 students); 4) MAN 1 Surakarta-Central Java (48 students); 5) MAN 1 Darussalam Ciamis-West Java (48 students); 6) MAN 2 MataramNTB (24 students); 7) MAN 1 Yogyakarta-DIY (24 students); 8) MAN Denanyar Jombang-East Java (48 students); 9) MAN 2 Samarinda-East Kalimantan (48 students); and 10) MAN 2 Martapura-South Kalimantan (48 students) (Admin, 2017).

Based on the explanation above, it can be understood that the SKB of three ministers is the culmination of the government's efforts in overcoming the gap between religious schools (madrasah) and public schools towards a unified national education system. With this decree, the integration of religious education and general education into the national education system has been achieved (Asrohah, 1999). Thus, it means that Islamic education cannot be separated from national education. Islamic education has become an integral and inseparable part of national education. Indirectly, the implications of this policy provide opportunities for madrasa graduates to carry out social and vertical mobility which has been limited to traditional educational institutions such as pesantren and madrasas. On the other hand, this opens up opportunities for madrasa graduates to enter work areas in the modern sector (Supiana, 2008, p. 44).

The emergence of the Three Ministerial Decree has advantages, namely, as an effort to modernize madrasas to be able to align the quality of education with equal public schools. However, on the other hand, the Three Ministerial Decree has a weakness, namely, it is able to stop the work of madrasa machines in producing graduates who are qualified as scholars. The solution to this weakness, the government is trying to make breakthroughs to restore the function of madrasas as places to produce religious leaders, namely by opening an alternative Madrasah Aliyah called Madrasah Aliyah Special Program (MAPK). This is an innovation in Islamic education because students who are accepted into MAPK are not random students but students who are selected through a strict selection. Students who are admitted to this madrasa (especially the Religious program) are required to live in the dormitory and are given additional lessons in the afternoon and use Arabic and English as the daily language in the dormitory. The main textbooks/lessons used are Arabic-language books. Viewed 
from this perspective, the presence of MAPK is essentially a form of progressive positive response from madrasas to the challenges they face.

In the 1976 curriculum which was further refined through the 1984 curriculum as stated in the Decree of the Minister of Religion No. 45 of 1987, has three features compared to the previous curriculum. First, the composition of the 1976 curriculum, with $70 \%$ general subjects, indicates that this curriculum is "more secular" than the previous one. Second, there is uniformity in the curriculum in most madrasah across Indonesia indicating that there are clear standards for academic achievement in madrasah education. This uniformity can be understood as from the government's support for madrasa modernization and political intervention in private madrasah. Third, the number of subjects taught indicates that the 1976 curriculum was simplified compared to the previous one. The number of subjects offered in the madrasah ibtidaiyah curriculum, for example, was reduced from 18 subjects in the 1973 curriculum to 13 subjects in the 1976 curriculum, while the same amount of time was allocated each week for study. Likewise, the madrasah tsanawiyah and madrasah aliyah curricula were reduced from 23 subjects each to 16 subjects for madrasah tsanawiyah and 19 subjects for madrasah aliyah (Zuhdi, 2006, p. 123).

Yahya said that Madrasas are Islamic educational institutions that have a long history of travel, until they were finally recognized as part of the National Education System. The existence of madrasas, which have been managed by the Ministry of Religion/MoRA for a long time through the religious sector, becomes a problem when faced with the regional autonomy law, which requires the management of the education sector to be handed over to local governments. In the end, the progress of madrasas lies not in being under the Ministry of Religion or the Ministry of Education but in the creativity of the madrasa itself (Yahya, 2014).

Nursikin in his research concluded that strengthening the existence of madrasas and Islamic schools to meet three minimum demands in improving the quality of Islamic madrasas and schools, namely (1) making madrasas and Islamic schools as a place to foster the spirit or practice of Islamic life, (2) strengthening the existence of Islamic schools. madrasas and Islamic schools so that they are equal to the school system, (3) Islamic madrasas and schools must be able to respond to future demands in order to anticipate the development of science and technology and the era of globalization (Nursikin, 2018). General lessons from madrasas and Islamic schools reach the same level as general subjects in general public schools of the same level. It was also stipulated that with the achievement of the level of general subjects in Islamic schools and madrasas that were the same as those in public schools, Islamic schools and madrasas and schools were recognized as having the same position, so that: (a) Madrasah and Islamic schools certificates could be obtained. have the same value as a public school diploma of the same level, (b) graduates of madrasas and Islamic schools can continue to higher level public schools, and (c) students of madrasas and Islamic schools can move to public schools of the same level (Nursikin, 2018).

Thus, gradually madrasas and Islamic schools (including Madrasah Aliyah) were integrated into the National Education System. The climax was the issuance of the Law on the National Education System (UUSPN) No. 2 of 1989 which strengthened the SKB. Even in the UUSPN policy, it is explicitly stated that madrasas (including MA/Islamic schools) are public schools with Islamic characteristics. Then it was strengthened by the National Education System Law No. 20 of 2003.

Awwaliyah and Baharun in their research concluded that looking at the reality at the present time, namely the slackness of Islamic values and eastern customs which 
are actually the identity of our country, is a proof concrete failure of Islamic Education as a national education system. If examined more deeply, there are several problems that really need to be overcome. To overcome these problems, the State then gives space to Islamic Education by stipulating in the Law on the National Education System that Islamic Education has a wider authority to contribute to directing people in the direction they aspire to (Baharun, 2018). Samrin further stated that the various multidimensional crises that hit Indonesia could not be seen and resolved from a mono-dimensional approach. The origin of the crisis is due to low morals and human morals, so Islamic education has a very large role in building a dignified national character and civilization (Samrin, 2015).

Masykur reinforces the statement above that Islamic religious education as a subject and value has not been able to provide a basic understanding that produces latent attitudes so that they can think, behave and behave according to the values of monotheism, humanity, balance and the value of rahmatan lil alamin cannot be instilled in students' personalities. . This failure is what experts later say that the nation's mental depravity and destruction, this condition is a reflection of the failure of the world of education in instilling values, more specifically the failure of the world of religious education (Masykur, 2015).

\section{Efforts to Strengthen Islamic Education in the National Education System}

During the Reformation Order, the existence of Islamic education was increasingly recognized, this is evidenced by the integration of Islamic education in the national education system. Haidar Putra Daulay stated that there are at least three things related to Islamic education in Law No. 20/2003, namely: First, formal, nonformal, and informal institutions place the madrasa as one of the formal educational institutions that are recognized as having equal existence with school education institutions. Second, Islamic education as a subject, namely religious lessons as one of the subjects that must be given to students in all lines, types and levels of education. Third, Islamic education as a value, there is a set of Islamic values in the national education system (Daulay, 2006).

a. Islamic Education as a

1) Formal Educational Institution

a) Article 17: Basic education is in the form of elementary school (SD) and Madrasah Ibtidaiyah (MI) or other equivalent forms and Junior High School (SMP) and Madrasah Tsanawiyah (MTs) or other equivalent forms.

b) Article 18: Secondary education takes the form of Senior High School (SMA), Madrasah Aliyah (MA), Vocational High School (SMK), and Vocational Madrasah Aliyah (MAK), or other equivalent forms.

c) Article 20: Higher Education can take the form of an Academy, Polytechnic, College, Institute, or University.

2) Non-formal Education Institutions (Article 26) Non-formal education units consist of course institutions, training institutions, study groups, community learning activity centers, taklim assemblies, and similar educational units.

3) Informal Education Institutions (Article 27) Informal educational activities carried out by families and the environment are in the form of independent learning activities.

4) Early Childhood Education (Article 28) Early childhood education in formal education is in the form of Kindergarten (TK), Raudhatul Athfal (RA), or other equivalent forms.

5) Religious education (Article 30) 
a) Religious education is organized by the government and or community groups of religious adherents in accordance with statutory regulations.

b) Religious education serves to prepare students to become members of the community who understand and practice the values of their religious teachings and/or become religious experts.

c) Religious education can be carried out through formal, non-formal, and informal education channels.

d) Religious education is in the form of diniyah education, pesantren, pasraman, pabhaya samena, and other similar forms.

e) The provisions regarding religious education as referred to in paragraphs $1,2,3$, and 4 are further regulated by government regulations (Indonesia, 2003).

b. Islamic Education as a Subject

Islamic education as a subject is at least regulated in the National Education System Law Number 20 of 2003, which is contained in several articles, namely:

1) Article 36 paragraph 3 explains that the curriculum is structured according to the level of education within the framework of the Unitary State of the Republic of Indonesia by paying attention to:

a. Increasing faith and piety.

b. Improvement of noble character.

c. Increased potential, intelligence, and interest of students.

d. Diversity of regional and environmental potential.

e. Demands for regional and national development.

f. The demands of the world of work.

g. The development of science and technology, and the arts.

h. Religion.

i. Global development dynamics.

j. National unity and national values (Indonesia, 2003).

2) In Article 37 paragraph 1, the curriculum for primary and secondary education must contain:

a) Religious education.

b) Civic education.

c) Language

d) Math.

e) Natural Sciences.

f) Social Sciences.

g) Arts and culture

h) Physical education and sports.

i) Skills/vocational.

j) Local content

3) In article 37 paragraph 2, the curriculum for higher education is mandatory:

a) Religious education.

b) Civic education.

c) Language.

1) every student in each educational unit has the right to receive religious education in accordance with the religion he adheres to and taught by educators of the same religion.

2) In the explanation section, it is also explained that religious educators and or religious teachers who are of the same religion as students are facilitated and/or 
provided by the government or local government in accordance with the needs of the education unit as stipulated in article 41 paragraph 3 (Hasbullah, Kapita selekta Pendidikan, 2016).

Based on the description above, it is clear that Islamic education has occupied a very important position in the national education system. The placement of these positions can be seen in two ways, namely Islamic education as an institution, and Islamic education as a subject. As an institution, it is marked by the establishment of Islamic educational institutions ranging from elementary school (SD) to university levels. Then as a subject, from elementary school to college there are already subjects of Islamic Religious Education.

In general, Law no. 20 of 2003 regarding Islamic education, conceptually has provided a strong foundation in developing and empowering the Islamic education system with the principles of democracy, decentralization, equity/justice, quality and relevance, and upholding human rights. So that independent education accountability is realized towards excellence. However, even so, the presenters feel the need to provide some notes about the proportion of Islamic education in the national education system, namely:

a) Structurally Islamic educational institutions are under the auspices of the Ministry of Religion due to structural barriers, so in terms of funding there are differences between educational institutions. which is managed by the Ministry of Religion with educational institutions managed by the Ministry of National Education so that it affects the quality of human resources, facilities and infrastructure and the quality of education in general.

b) The supervision system for the implementation of the National Education System Law on a national and regional scale, especially related to Islamic education, has not received attention.

c) The national education system is still unstable (Huda, 2001).

As a sub-system in national education, to identify the various problems faced by Islamic education, of course, it refers to the problems of education nationally. National education carries out at least four functions:

1) Transmission of culture, knowledge, attitudes, values, and norms.

2) Choose to teach social roles:

3) Ensure social integration

4) Conduct social innovations.

Based on this function, it is clearly seen that Islamic education, even though in the Indonesian context is a sub-system, its mission and role are not much different from the role of national education. To carry out its functions effectively and efficiently, an education system must be healthy and keep moving in accordance with the changing movements of world society in general and Indonesia in particular. In the context of Islamic education in this country, it is clear that the problems faced are far more complex than general education. As an example of the simplest problem, we do not yet have a tool such as a manual that can be used to organize Madrasah Diniyyah. Especially for the arrangement of the Islamic education system in the national scope. The logical consequences of this reality include the inability of Islamic education to meet the logic of competition in the world of national education. Even though by Muslims themselves, most Islamic educational institutions are considered less able to meet their needs, let alone meet their tastes. If we look closely, Islamic education is still 'second class' and has not been able to become an alternative education, among others, due to several factors, including: 
1) Internal barriers, because the underlying philosophy is not yet clear, as an implication, several symptoms can be seen, including:

- Absence of standard curriculum as a boundary line against other education systems.

- There is no standard methodology.

- There is no reliable measuring tool in assessing educational outcomes.

2) External barriers:

- Still too dependent on the pattern of education outlined by the government, namely education to support development.

- Lack of funds and facilities, so that Islamic education is oriented to consumer tastes, and supports the marginalized.

- The national education system is still unstable (Azzahra).

On the other hand, there are also several obstacles that can hinder the existence of Islamic education nationally, including: The development of culture and rapid changes in society, so that Islamic education is increasingly powerless to compete with the rate of change in society. The public's appreciation of Islamic educational institutions has not been encouraging. The existence of social stratification which is based on all materialistic measures and causes people to compete to attack favorite educational institutions, without heeding the ideological aspects hidden behind them. There is a tendency to mismanagement, for example unhealthy competition between leaders and closed leadership.

A few years ago there was a very serious problem for the alumni of Islamic Higher Education, where they could not take the CPNS test because they were considered equally as Islamic religious education teachers, even though Islamic universities had produced various competent alumni in their fields. For example, tadris English produces competent graduates as teachers of English subjects in schools, both public and religious. However, because their academic degrees contain the word "Islam", for example, a tadris degree in English has a bachelor's degree in S.Pd.I (Bachelor of Islamic Education). This title is considered by them to only be in charge of Islamic religious education. But in the end, the Director General of Islamic Education responded to this quickly and precisely by changing the nomenclature of undergraduate degrees to suit the scientific field, finally the English language study program also held a S.Pd (Bachelor of Education) degree. Thus they get the same treatment and rights as alumni of public universities.

To anticipate the obstacles above, and even just to survive in a reasonable connotation, there are some urgent things to do. 1) Islamic education should be more adaptive, accommodating, and leave the status quo. 2) Islamic education must lead to integration between religious and general sciences. 3) Islamic education should pay attention to more intense foreign language content, especially Arabic and English. 4) Islamic education is designed and managed in such a way that it can foster the ability to be self-reliant and independent in life. 5) Islamic educational institutions are increasingly reaffirming their commitment to establish themselves as institutions labeled Islam. 6) Islamic education experts need to immediately solve the internal scientific problems in Islamic education.

When the obstacles can be found the best solution, it is very likely that Islamic education can survive nationally. So that the existence of education can contribute to national development and be taken into account on a national scale.

This is reinforced by Muhaimin (2005) meanwhile, in Indonesia, seen from its history, there are at least two important factors behind the emergence of madrasas, 
namely: first, there is a view that the traditional Islamic education system is felt to be unable to meet the pragmatic needs of the community; second, there are concerns over the rapid development of Dutch schools which will lead to the development of secularism, so the Muslim community, especially reformers, is trying to make efforts to develop education and empower madrasas.

Education in Indonesia has been running in a dualistic way of education (general and religious), there is a separation between general science and religious science. This has happened since the colonial government of Balanda introduced a secular education system, while Islamic education represented by pesantren did not pay attention to general knowledge, until Indonesia's independence, although at the beginning of independence it still inherited a dualistic education system.

Islamic education in Indonesia in its long history, starting from the colonial period until Indonesia's independence, has faced various problems and gaps in various aspects, in the form of the dichotomy of education, curriculum, goals, resources, and management of Islamic education. So Azra said that Islamic education is as seen in the preparation of the 2003 National Education System Law, although there are some articles that have not been consistently realized by the government, for example Article 49 paragraph 12 concerning the education budget (Azra, 1999). Meanwhile, Sanaky said that the government's efforts to improve Islamic education in Indonesia can be seen from their commitment in the preparation of the 2003 National Education System Law, although the improvements have not been carried out in a basic way, so that it seems modest (Sanaky, 2004; Kristiawan, et al., 2021). Efforts to reform and improve Islamic education are often piecemeal or not comprehensive and comprehensive and most Islamic educational systems and institutions have not been managed professionally.

\section{CONCLUSION}

Islamic education in Indonesia has gone through a long journey until it finally received national recognition. This recognition is contained in regulations that support and strengthen the existence of Islamic education nationally. In its journey, Islamic education certainly experiences various kinds of obstacles and obstacles, both internally and externally. Therefore, it is necessary to strengthen the position of Islamic education in the national education system. This strengthening is shown by the institutions and human resources of Islamic education itself, both in quantity and quality. Education must be at the forefront of everything, so that its existence can be recognized nationally.

\section{ACKNOWLEDGEMENTS}

The researchers express gratitude and appreciation for the trust that has been given by Universitas Nurdin Hamzah Jambi, Sekolah Tinggi Agama Islam Al-Furqan Makassar, and Institut Agama Islam Negeri (IAIN) Metro Lampung.

\section{AUTHOR CONTRIBUTION STATEMENTS}

The authors had contribution for collecting data in this research. The authors help to improve this research paper before submit to journal. 


\section{REFERENCES}

Asnawan, A. (2021). Enhancement Integrated Quality Management in Islamic Education Institutions. Bulletin of Science Education, 1(1), 42-49.

Azra, A. (2009). Pendidikan islam: tradisi dan modernisasi menuju milenium baru. Jakarta: Logo Wacana Ilmu.

Azzahra, R. (nd). Pendidikan islam dalam sistem pendidikan nasional. Kebumen: PGMI STAINU.

Baharun, RA (2018). Pendidikan islam dalam sistem pendidikan nasional: telaah epistemologi terhadap problematika pendidikan islam. Jurnal Ilmiah Didaktika Vol. 19 No. 1, 34-49.

Daulay, HP (2016). Pendidikan islam dalam sistem pendidikan nasional di indonesia. Jakarta: Kencana.

Fajrussalam, H., Ruswandi, U., \& Arifin, B. S. (2021). Spotlight and Criticism of Islamic Religious Education in Schools. Bulletin of Science Education, 1(1), 91-96.

Fitriani, MM (2014). Problematika pendidikan islam sebagai sub sistem pendidikan nasional di era global. Jurnal at-Tahrir Vol. 11 No. 2, 303-325.

Hadna, A. H., \& Kartika, D. (2017). Evaluation of poverty alleviation policy: Can conditional cash transfers improve the academic performance of poor students in Indonesia?. Cogent Social Sciences, 3(1), 1295548.

Hasbullah. (2016). Kapita selekta pendidikan. Jakarta: Rajawali Press.

Hasbullah. (2016). Sejarah pendidikan islam di indonesia: lintasan sejarah pertumbuhan dan perkembangan. Jakarta: LSIK.

Huda, AK (2001). Paradigma pendidikan islam. Semarang: Pustaka Pelajar.

Indonesia. (2003). undang-undang Nomor 20 Thaun 2003 tentang sistem pendidikan nasional. Jakarta: Departemen Pendidikan Nasional.

Ismail. (2010). Politik pendidikan madrasah di indonesia pasca kemerdekaan: 19452003. Jurnal Ta'dib Vol. XV No. 02, 165-212.

Kristiawan, M., Suhono, S., Yussof, M. H. B., \& Muslimah, M. (2021). The International School's Culture in Indonesia and Brunei Darussalam. Jurnal Iqra': Kajian Ilmu Pendidikan, 6(1), 180-191.

Lee, J., \& Ryu, J. S. (2019). Current status of parasite infections in Indonesia: a literature review. The Korean journal of parasitology, 57(4), 329.

Mahfud, C. (2019). Evaluation of Islamic Education Curriculum Policy in Indonesia. Premiere Educandum: Jurnal Pendidikan Dasar dan Pembelajaran, 9(1), $34-43$.

Maksum. (1999). Madrasah: sejarah dan perkembangannya. Jakarta: Logos.

Masykur, H. (2015). Eksistensi dan fungsi pendidikan agama islam dalam sistem pendidikan nasional. (Skripsi). Salatiga: Jurusan PAI, FTIK IAIN Salatiga.

Muhaimin. (2005). Pengembangan kurikulum pendidikan agama islam di sekolah, madrasah dan perguruan tinggi. Jakarta: PT RajaGrafindo Persada.

Nursikin, M. (2018). Eksistensi madrasah dan sekolah islam sebagai lembaga pendidikan islam dalam sistem pendidikan nasional: studi kasus di MAN Yogyakarta III dan SMA Muhammdiyah 1 Yogyakarta. Jurnal Istawa: Jurnal Pendidikan Islam Vol. 3 No. 1, 27-58.

Rahim, H. (2005). Madrasah dalam politik pendidikan di indonesia. Jakarta: Logos.

Romlah, O. Y., \& Latief, S. (2021). Empowering the Quality of School Resources in Improving the Quality of Education. Bulletin of Science Education, 1(1), 37-41.

Salim, MH (2012). Studi ilmu pendidikan islam. Yogyakarta: Ar-Ruzz Media. 
Samrin. (2015). Pendidikan agama islam dalam sistem pendidikan nasional di indonesia. Jurnal al-Ta' dib Vol. 8 No. 1, 101-116.

Sanaky, H. (2004). Paradigma pendidikan islam. Yogyakarta: Safiria Insania Press.

Setiyanto, A., Subandi, S., \& Fadillah, M. K. (2021). The Problems of Islamic Education Learning at Islamic Vocational High School Raden Fatah Tugumulyo, South Sumatra. Bulletin of Pedagogical Research, 1(1), 83-105.

Setiawan, A. R. (2020). Introducing the Indonesian Education System (Doctoral dissertation, Thesis Commons. DOI: https://doi. org/10.31237/osf. io/ygt5c).

Soebahar, AH (2013). Kebijakan pendidikan islam: dari ordinasi guru sampai UU sisdiknas. Jakarta: Rajawali Press.

Supiana. (2008). Sistem pendidikan madrasah unggulan di mAN Insan Cendikia, MAN 1 Bandung, dan MAN Darussalam Ciamis. Jakarta: Badan Litbang dan Diklat Departemen Agama RI.

Syafutra, S., Montessori, M., \& Suhono, S. (2021). Local Awareness in Making Social Integration of Society at Mendahara District. JMKSP (Jurnal Manajemen, Kepemimpinan, dan Supervisi Pendidikan), 6(2), 278-292.

Wahyuni, W., Jannah, S. R., \& Fadillah, K. (2021). The Role of Teacher Islamic Education in Shaping Student Morals at State Junior High School 03 Baradatu Way Kanan Regency. Bulletin of Pedagogical Research, 1(1), 136-146.

Yahya, MD (2014). Posisi madrasah dalam sistem pendidikan nasional di era otonomi daerah. Jurnal Khazanah Vol. XII No. 1, 78-101.

Zuhdi, M. (2006). Political and social influences on religious school: a historical perspective on indonesian islamic school curricula. Canada: McGill University.

Zuhdi, M. (2021). Improving Civics Education Learning Outcomes in 1908 National Awakening Spirit Materials by Using Problem Solving Learning Methods. Bulletin of Pedagogical Research, 1(2), 252-262.

Copyright Holder :

(C) Latief, S., et al., (2021)

First Publication Right :

๑) IJoASER (International Journal on Advanced Science, Education, and Religion)

This article is under:

CC BY SA 